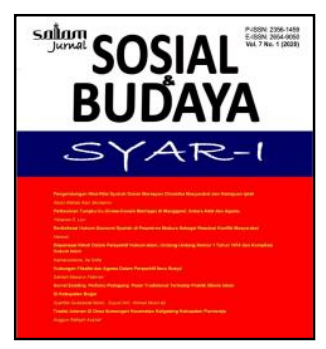

P-ISSN: 2356-1459. E-ISSN: 2654-9050

Vol. 8 No. 2 (2021), pp. 467-484

DOI: 10.15408/sjsbs.v8i2.19904

http://journal.uinjkt.ac.id/index.php/salam/index

\title{
Rekonsepsi Lembaga Pengawas terkait Perlindungan Data Pribadi oleh Korporasi sebagai Penegakan Hak Privasi berdasarkan Konstitusi*
}

\author{
Imas Novita Juaningsih", Rayhan Naufaldi Hidayat², Kiki Nur Aisyah ${ }^{3}$, \\ Dzakwan Nurirfan Rusli ${ }^{4}$ \\ Universitas Islam Negeri Syarif Hidayatullah Jakarta
}

d.

10.15408/sjsbs.v8i2.19904

\begin{abstract}
The right to privacy is a personal right of every individual which must be protected by the state in accordance with the mandate of the constitution. Along with the development of information and communication technology, the discourse regarding the right to privacy has come under the spotlight again given the high intensity of personal data utilization, especially by corporations in the digital business era. This research will further analyze the use of consumer personal data by corporations from a legal perspective. The research method used is library research through a statute approach. The results of this study indicate that there is still obesity in regulations related to personal data protection in Indonesia, where the total reaches 30 regulations in various sectors. Moreover, this reality is exacerbated by the inadequacy of the Ministry of Communication and Information Technology (Kominfo) in conducting surveillance and investigations related to personal data protection. The result of all of this is the creation of legal loopholes that are often exploited to carry out crimes in the form of hacking and theft of personal data that harm consumers and the wider community. Therefore, there is a need for legal reform accompanied by a reconception of supervisory agencies regarding the protection of personal data as an integral part of upholding privacy rights in an era of constitutional disruption.
\end{abstract}

Keywords: Personal Data Protection, Privacy Rights, Corporation, Constitution

\begin{abstract}
Abstrak
Hak privasi merupakan hak pribadi setiap individu yang wajib dilindungi oleh negara sesuai dengan amanat konstitusi. Seiring dengan perkembangan teknologi informasi dan komunikasi, diskursus perihal hak privasi kembali mendapat sorotan mengingat tingginya intensitas pemanfaatan data pribadi, terutama oleh korporasi di era bisnis digital. Penelitian kali ini akan menganalisa lebih jauh terkait penggunaan data pribadi konsumen oleh korporasi dari perspektif hukumnya. Adapun metode penelitian yang digunakan adalah penelitian kepustakaan melalui pendekatan perundang-undangan (statute approach). Hasil dari penelitian ini menunjukkan bahwa masih terjadinya obesitas regulasi terkait perlindungan data pribadi Di Indonesia, dimana totalnya mencapai 30 Undang-Undang di
\end{abstract}

* Received: January 25, 2021, Revision: January 30, 2021, Published: April 1, 2021.

1 Researcher at Psokolegnas/Ilmu Hukum UIN Syarif Hidayatullah Jakarta, imas.juaningsih18@mhs.uinjkt.ac.id

2 Ilmu Hukum UIN Syarif Hidayatullah Jakarta, rayhan.naufaldi18@mhs.uinjkt.ac.id

${ }^{3}$ Ilmu Hukum UIN Syarif Hidayatullah Jakarta, kiki.nuraisyah19@mhs.uinjkt.ac.id

${ }^{4}$ Ilmu Hukum UIN Syarif Hidayatullah Jakarta, dzakwan.nurirfan18@mhs.uinjkt.ac.id 
berbagai sektor. Terlebih, realita tersebut semakin diperburuk dengan tidak optimalnya Kementrian Komunikasi dan Informatika (Kominfo) dalam melakukan pengawasan dan investigasi terkait perlindungan data pribadi. Akibat dari semua itu ialah terciptanya celah hukum yang kerap kali dieksploitasi untuk melancarkan kejahatan berupa peretasan dan pencurian data pribadi yang merugikan konsumen serta masyarakat dalam cakupan yang lebih luas. Oleh karena itu, diperlukannya reformasi hukum yang diiringi dengan rekonsepsi lembaga pengawas terkait perlindungan data pribadi sebagai bagian integral dari penegakan hak privasi di era disrupsi berdasarkan konstitusi.

Kata kunci: Perlindungan Data Pribadi, Hak Privasi, Korporasi, Konstitusi

\section{A. PENDAHULUAN}

Privasi merupakan hak setiap individu yang sangat fundamental untuk dilindungi guna menjaga integritas dan martabat pribadi. ${ }^{5}$ Westin menjelaskan bahwa privasi sebagai hak individu, kelompok, atau lembaga untuk menentukan kapan, bagaimana dan sejauh mana informasi tentang mereka dikomunikasikan kepada orang lain. ${ }^{6}$ Pembahasan mengenai hak privasi kembali mengemuka dengan maraknya penggunaan teknologi informasi yang diiringi dengan tuntutan keterbukaan informasi dan data terutama yang dikuasai oleh berbagai perusahaan digital. ${ }^{7}$ Data dan informasi pribadi erat kaitannya dengan konsep kerahasiaan yang menjadi hak privasi setiap orang sebagai satu kesatuan dari hak asasi manusia. ${ }^{8}$

Penghormatan, perlindungan dan penegakan hak atas privasi hakikatnya merupakan tanggung jawab negara ${ }^{9}$ sebagaimana amanat dari Pasal 28 G ayat (1) Undang-Undang dasar Negara Republik Indonesia Tahun 1945. Berbagai peraturan perundang-undangan yang menindaklanjuti amanat tersebut, sayangnya masih tersebar ke dalam beberapa sektor dengan total 30 Undang-Undang, di mana realitas tersebut menunjukkan bahwa regulasi terkait data pribadi yang berlaku hingga saat ini masih bersifat sektoral dan parsial, sehingga tidak sistematis. ${ }^{10}$ Selain itu, peraturan yang ada juga masih belum bersifat komprehensif, terutama dalam hal pengawasan korporasi. Padahal korporasi merupakan pihak yang mengumpulkan, mengolah dan memproses data pribadi konsumen dalam melangsungkan kegiatan bisnisnya. ${ }^{11}$

Problematika terkait regulasi perlindungan data pribadi menggambarkan urgensitas akan pentingnya perancangan suatu regulasi yang bersifat khusus. Tidak adanya regulasi khusus terkait perlindungan data pribadi merupakan pengkhianatan dari amanat konstitusi yang menggariskan negara untuk menjamin hak pribadi warga

${ }^{5}$ Wahyudi dan Asep Komarudin Djafar, Perlindungan Hak Atas Privasi Di Internet Beberapa Penjelasan Kunci (Jakarta: Elsam, 2014), hlm 2.

${ }^{6}$ Alan Westin, Privacy and Freedom (New York: Atheneum, 1967), hlm 7.

7 Anggara dkk, Menyeimbangkan Hak: Tantangan Perlindungan Privasi Dan Menjamin Akses Keterbukaan Informasi Dan Data Di Indonesia (Jakarta: Institute for Criminal Justice Reform, 2015), hlm 1.

8 Sinta Dewi, "Konsep Perlindungan Hukum Atas Privasi Dan Data Pribadi Dikaitkan Dengan Penggunaan Cloud Computing Di Indonesia," Yustisia 5, no. 1 (2016): hlm 25.

9 Eko Hidayat, "Perlindungan Hak Asasi Manusia Dalam Negara Hukum Indonesia," Jurnal Hukum Ekonomi Syariah 8, no. 2 (2016): hlm 81.

${ }^{10}$ Denico Doly, "Politik Hukum Pengaturan Perlindungan Data Pribadi," Pusat Penelitian Badan Keahlian DPR RI 10, no. 8 (2018): hlm 3.

${ }^{11}$ Setiyono, Kejahatan Korporasi (Malang: Bayumedia, 2003), hlm 21-22. 
negara secara paripurna. Di samping tidak adanya peraturan yang bersifat spesifik, sistem pengawasan yang dilakukan oleh Kominfo di ranah implementasi pun masih bersifat pasif, terutama dalam hal investigasi. Hal itu membuat sistem pengawasan yang dijalankan oleh Kominfo menjadi tidak optimal.

Ketidakoptimalan Kominfo terutama sub bidang perlindungan data pribadi dalam mengawasi keamanan siber pada korporasi ditunjukkan dengan banyaknya pelanggaran yaitu sebesar $30 \% .^{12}$ Pelanggaran tersebut berupa kasus peretasan dan pencurian data pribadi yang dilakukan oleh pelaku kejahatan untuk melancarkan serangan siber (cyber-attack). ${ }^{13}$ Besarnya pelanggaran tersebut juga dikarenakan maraknya korporasi yang tidak patuh terhadap standardisasi yang diterapkan berdasarkan Peraturan Pemerintah No. 71 Tahun 2019, Peraturan Pemerintah No. 80 Tahun 2019 dan Peraturan Menteri Komunikasi dan Informatika No. 20 Tahun 2016 yang secara keseluruhan mengatur terkait standardisasi keamanan sistem elektronik. Hipotesis tersebut terbukti dari masifnya kasus serangan siber berupa peretasan dan pencurian data pribadi yang terjadi di Indonesia selama 2017 hingga 2020. Total kasus peretasan dan pencurian data pribadi dalam kurun waktu tiga tahun terakhir itu sebesar 552 kasus. Rata-rata peningkatan kasus sekitar 50\% setiap tahunnya dengan jumlah mencapai 134,8 juta data pribadi yang berhasil dicuri. ${ }^{14}$

Kasus-kasus tersebut memiliki cakupan yang cukup luas, di antaranya berdampak pada konsumen, korporasi, dan negara. Konsumen sebagai pemilik data kerap kali menjadi objek pemasaran langsung (direct marketing) dari berbagai perusahaan yang dapat menderogasi hak atas kedamaian dan kenyamanan pada diri konsumen. Hal itu dikarenakan konsumen senantiasa mendapatkan teror berupa telefon dan Short Message Service (SMS) dari para staf marketing untuk mempromosikan produk atau jasa. ${ }^{15}$

Rangkaian dampak buruk yang dialami konsumen setidaknya menimbulkan keraguan untuk menyebarluaskan data pribadi miliknya, karena kerap kali disalahgunakan untuk kepentingan penjualan data, pemasaran, data profiling dan spionase. Praktik tersebut membuat konsumen menjadi terusik privasinya, sehingga berimplikasi pada munculnya rasa tidak percaya (distrust) konsumen terhadap korporasi sebagai pengelola data. ${ }^{16}$ Dalam cakupan yang lebih luas, data pribadi yang telah disalahgunakan kerap kali dimanfaatkan untuk melakukan kejahatan yang meliputi pembuatan akun palsu, penipuan dalam jaringan, pencucian uang dan

\footnotetext{
12 Ahmad Budi Setiawan, "Revolusi Bisnis Platform Sebagai Penggerak Ekonomi Digital Di Indonesia," Masyarakat Telematika Dan Informasi 9, no. 1 (2018): hlm 69.

${ }^{13}$ Oona A dkk Hathaway, “The Law Of Cyber Attack," California Law Review 100, no. 4 (2012): hlm 837.

${ }^{14}$ Divisi Humas POLRI, “Menanti Ketegasan Komitmen Menjaga Keamanan Data Pribadi,” 2020.

15 Lia Sautunnida, "Urgensi Undang-Undang Perlindungan Data Pribadi Di Indonesia Studi Perbandingan Hukum Inggris Dan Malaysia," Kanun 20, no. 2 (2018): hlm 370.

${ }^{16}$ Sinta Dewi, "Perlindungan Privasi Dan Data Pribadi Dalam Era Ekonomi Digital Di Indonesia," Veritas et Justitia 4, no. 1 (2018): hlm 170.
} 
transaksi ilegal. ${ }^{17}$ Konsekuensi logis dari semua itu ialah terancamnya keamanan dan kedamaian negara. ${ }^{18}$

Berdasarkan problematika yang telah penulis paparkan, maka penulis tertarik untuk membahas dan menganalisa lebih dalam terkait perlindungan data pribadi konsumen yang dimanfaatkan oleh berbagai korporasi Di Indonesia dari sudut pandang hukum. Adapun inti dari pembahasan tersebut dapat dirumuskan menjadi beberapa pertanyaan sebagai berikut. Pertama, apa saja problematika hukum yang berkenaan dengan perlindungan data pribadi Di Indonesia? Kedua, bagaimana gambaran terkait relevansi perlindungan data pribadi dengan korporasi dalam kerangka konstitusi? Terakhir, bagaimana konsep lembaga pengawas terkait perlindungan data pribadi yang ideal?

\section{B. METODE PENELITIAN}

Penelitian pada artikel ini ialah penelitian kepustakaan. Pendekatan yang digunakan dalam penelitian kali ini adalah statue approach yang menempatkan ketentuan normatif dalam peraturan perundang-undangan sebagai landasan utama dalam penelitian. Data yang peneliti butuhkan berupa informasi terkait norma hukum yang mengatur perihal data pribadi dan statistik terkait tindak kejahatan yang memanfaatkan data pribadi. Data-data tersebut diperoleh dari peraturan perundangundangan yang berlaku di Indonesia dan laporan dari berbagai instansi pemerintahan yang berwenang.

Seluruh data yang dibutuhkan dalam penelitian kali ini dikumpulkan dengan melakukan studi dokumen. Peneliti memeriksa dan membaca semua peraturan perundang-undangan, berbagai laporan dari instansi pemerintahan, dan literaturliteratur yang relevan dengan permasalahan yang sedang diteliti. Setelah itu, data-data yang telah diperoleh sebelumnya dianalisa dengan metode deskriptif. Metode tersebut digunakan untuk menggambarkan pokok permasalahan dan solusi yang tepat untuk mengatasinya.

\section{HASIL TEMUAN DAN PEMBAHASAN}

\section{Problematika Hukum terkait Perlindungan Data Pribadi Di Indonesia}

Negara Indonesia menganut paham bahwa pelaksanaan kekuasaan harus dijalankan berdasarkan hukum sebagai supremasi tertinggi sebagaimana konsep negara hukum (Rechtsstaat). ${ }^{19}$ Konsep tersebut menegaskan bahwa konstitusi sebagai hukum

17 Edmon Makarim, Pengantar Hukum Telematika (Suatu Kompilasi Kajian) (Jakarta: Rajagrafindo Persada, 2005), hlm 170.

${ }^{18}$ Mareza Efendi, “Penyalahgunaan Kartu Tanda Penduduk (KTP) Untuk Registrasi Kartu Perdana (HP) Menurut Undang-Undang No.19 Tahun 2016 Tentang Informasi Transaksi Elektronik (ITE) Ditinjau Dari Fiqh Jinayah," Repository UIN Raden Fatah, 2020, hlm 2, http://repository.radenfatah.ac.id/6912/.

${ }^{19}$ Azharai, Negara Hukum Indonesia, Analisis Yuridis Normatif Tentang Unsur-Unsurnya (Jakarta: UIPress, 1995), hlm 12. 
tertinggi memiliki peranan yang sangat krusial dalam setiap penyelenggaraan kehidupan berbangsa dan bernegara. ${ }^{20} \mathrm{Hal}$ itu dikarenakan konstitusi berperan sebagai pedoman yang menunjukkan arah dalam mencapai tujuan utama yang dicitakan. ${ }^{21}$ Salah satu bukti konkret dari postulat tersebut yaitu dapat dilihat dari muatan konstitusi yang telah mengandung prinsip pembatasan kekuasaan, perlindungan hak asasi manusia dan kewajiban negara. ${ }^{22}$

Jaminan atas perlindungan hak asasi setiap warga negara pada hakikatnya telah termaktub dalam Undang-Undang Dasar Negara Republik Indonesia Tahun 1945 (UUD NRI 1945) yang berlaku sebagai konstitusi negara. Hal itu dapat dibuktikan dengan adanya Pasal 28 G ayat (1) UUD NRI 1945 yang berbunyi "setiap orang berhak atas perlindungan diri pribadi, keluarga, kehormatan, martabat, dan harta benda yang di bawah kekuasaannya, serta berhak atas rasa aman dan perlindungan dari ancaman ketakutan untuk berbuat atau tidak berbuat sesuatu yang merupakan hak asasi sebagaimana yang telah termaktub dalam konstitusi. Tanggung jawab negara yang bersumber dari UUD NRI 1945 terkait perlindungan data pribadi sebagai bagian dari hak privasi setiap warga negara semakin dipertegas dengan turut sertanya Negara Republik Indonesia dalam Deklarasi Hak Asasi Manusia Association of Southeast Asian Nations (ASEAN), di mana dalam Article of 21 ASEAN Declaration of Human Rights menegaskan bahwa "Every person has the right to be from arbitry interference with his or her privacy, family, home or correspondence including personal data, or to attacks upon that person's honour and reputation. Every person has the right to the protection of the law against such interference or attacks". Lebih lanjut, Putusan Mahkamah Konstitusi Nomor 006/PUU-I/2003 menegaskan bahwa pengaturan terkait perlindungan data pribadi harus dimuat dalam bentuk undangundang yang bersifat khusus.

Berkaca pada realita yang terjadi saat ini, regulasi perlindungan data pribadi Di Indonesia belum dituangkan ke dalam bentuk undang-undang khusus yang bersifat komprehensif dan sistematis. ${ }^{23}$ Regulasi terkait perlindungan data pribadi, terutama di sektor bisnis yang melibatkan korporasi secara eksplisit masih terpisah dan terpecahpecah di berbagai tingkat perundang-undangan di Indonesia, bahkan di masing-masing sektor yang berbeda, beberapa sektor di antaranya dapat dilihat dalam tabel di bawah ini:

Tabel Regulasi Perlindungan Data Pribadi terkait Korporasi

\begin{tabular}{|l|l|l|l|}
\hline No & Sektor & Regulasi & Pasal \\
\hline 1 & $\begin{array}{l}\text { Perdagangan dan } \\
\text { Perindustrian }\end{array}$ & $\begin{array}{l}\text { Undang-Undang No. 8 Tahun 1997 tentang } \\
\text { Dokumen Perusahaan }\end{array}$ & Pasal, 1 \& 2 \\
\hline
\end{tabular}

${ }^{20}$ M. Agus Santoso, “Perkembangan Konstitusi Di Indonesia," Yustisia 2, no. 3 (2013): hlm 120.

${ }^{21}$ Ni'Matul Huda, Negara Hukum, Demokrasi Dan Judicial Review (Yogyakarta: UII-Press, 2005), hlm

1.

${ }^{22}$ Utrecht, Pengantar Hukum Administrasi Negara Indonesia (Surabaya: Pustaka Tinta Mas, 1986), hlm

19.

${ }^{23}$ Setyawati Fitri Anggraeni, “Polemik Pengaturan Kepemilikan Data Pribadi : Urgensi Untuk Harmonisasi Dan Reformasi Hukum Di Indonesia," Jurnal Hukum E Pembangunan 48, no. 4 (2018): hlm 819. 


\begin{tabular}{|c|c|c|c|}
\hline & & $\begin{array}{l}\text { Undang-Undang No. } 8 \text { Tahun } 1999 \text { tentang } \\
\text { Perlindungan Konsumen }\end{array}$ & Pasal, 9 ayat (1) \\
\hline & & $\begin{array}{l}\text { Undang-Undang No. } 7 \text { Tahun } 2014 \text { tentang } \\
\text { Perdagangan }\end{array}$ & $\begin{array}{l}\text { Pasal, } 65 \text { ayat (5) \& } \\
\text { Pasal } 66\end{array}$ \\
\hline \multirow[t]{2}{*}{2} & \multirow[t]{2}{*}{$\begin{array}{ll}\text { Keuangan dan } \\
\text { Perbankan }\end{array}$} & $\begin{array}{l}\text { Undang-Undang No. } 10 \text { Tahun } 1998 \text { tentang } \\
\text { Perbankan }\end{array}$ & $\begin{array}{l}\text { Pasal, } 1 \text { ayat }(28), \\
40 \& 47\end{array}$ \\
\hline & & $\begin{array}{l}\text { Undang-Undang No. } 21 \text { Tahun } 2008 \text { tentang } \\
\text { Perbankan Syariah }\end{array}$ & $\begin{array}{l}\text { Pasal } 41,42 \text { ayat }(1), 49,50 \\
\& \text { Pasal } \\
60\end{array}$ \\
\hline \multirow[t]{3}{*}{3} & \multirow{3}{*}{$\begin{array}{l}\text { Sektor } \\
\text { Telekomunikasi } \\
\text { Informatika }\end{array}$} & $\begin{array}{l}\text { Undang-Undang No. } 36 \text { Tahun } 1999 \text { tentang } \\
\text { Telekomunikasi }\end{array}$ & Pasal $40 \& 42$ \\
\hline & & $\begin{array}{l}\text { Undang-Undang No. } 19 \text { Tahun } 2016 \text { tentang } \\
\text { Informasi dan Transaksi Elektronik (ITE) }\end{array}$ & $\begin{array}{l}\text { Pasal 26, Pasal } 43 \text { ayat (2) } \\
\text { dan (3), Pasal 38, Pasal 31, } \\
\text { Pasal } 47\end{array}$ \\
\hline & & $\begin{array}{l}\text { Undang-Undang No. } 14 \text { Tahun } 2008 \text { tentang } \\
\text { Keterbukaan Informasi Publik }\end{array}$ & $\begin{array}{l}\text { Pasal } 1 \text { ayat (1), } 6 \text { ayat (3) } \\
\text { huruf (c), Pasal } 17 \text { huruf } \\
\text { (g)- } \\
\text { (h), Pasal } 23 \text { dan } 26\end{array}$ \\
\hline
\end{tabular}

Berbagai peraturan dilingkup undang-undang yang masih bersifat parsial sedikitnya menimbulkan kegagalan dalam memberikan road map yang jelas terkait konsep perlindungan data pribadi yang tepat untuk diberlakukan di Indonesia. ${ }^{24} \mathrm{Hal}$ itu berimplikasi pada tidak jelasnya konsep pengawasan terhadap korporasi sebagai pihak yang melakukan pengumpulan, pengolahan, dan pemrosesan data pribadi para konsumen. Apabila mengacu pada Pasal 35 dan 56 Peraturan Pemerintah No. 71 Tahun 2019 Jo. Pasal 76 ayat (2) Peraturan Pemerintah No. 80 Tahun 2019, leading sector dalam proses pengawasan dipegang oleh Kementerian Komunikasi dan Informatika (Kominfo) beserta instansi lainnya yang bersifat sektoral. Ketentuan tersebut memperlihatkan kekeliruan konsep yang sangat nyata.

Kekeliruan konsep pengawasan yang telah dijalankan oleh Kominfo dapat dibuktikan dengan tidak tercantumnya ketentuan mengenai mekanisme koordinasi antara sub bidang perlindungan data pribadi Kominfo dengan data officer dari korporasi pada Pasal 35 ayat (3) Peraturan Menteri Komunikasi dan Informatika (Permen Kominfo) No. 20 Tahun 2016. Pasal a quo hanya menunjukkan bahwa "Menteri berwenang meminta data dan informasi dari penyelenggara sistem elektronik dalam rangka perlindungan data pribadi". Dengan tidak diaturnya pola koordinasi antara Kominfo dan korporasi secara jelas, maka sistem pelaporan berkala (annual report) tidak dapat berjalan sebagaimana mestinya.

${ }^{24}$ Emily Linn, “A Look Into the Data Privacy Crystal Ball: A Survey of Possible Outcomes for the EU-U.S Privacy," Vanderbilt Journal of Transnational Law 50 (2017): hlm 1358. 
Tidak hanya sampai disitu, kewenangan Kominfo terkait mekanisme investigasi atas temuan pelanggaran dari proses pengawasan masih belum diatur pula dalam Permen Kominfo. ${ }^{25}$ Dalam Pasal 36 Permen Kominfo, ketentuan yang telah diatur hanya mengenai mekanisme penjatuhan sanksi. Hal itu berimplikasi pada ketidaksesuaian sanksi yang dijatuhkan kepada korporasi karena tidak terselenggaranya mekanisme investigasi yang bersifat holistik sebelumnya. Berbagai permasalahan yang berada pada sub bidang perlindungan data pribadi direktorat aplikasi dan informatika (Kominfo) membuat korporasi menjadi tidak patuh, sehingga berimplikasi pada ketidakamanan sistem elektronik sebagai pusat aktifitas pengelolaan data pribadi konsumen.

Konsekuensi logis dari lemahnya pengawasan terhadap korporasi membuat banyaknya pelanggaran yang dilakukan korporasi sebesar 30\%. ${ }^{26}$ Mayoritas pelanggaran tersebut berupa ketidak patuhan korporasi dalam mengikuti standardisasi yang telah ditentukan berdasarkan Pasal 14 Peraturan Pemerintah No. 71 Tahun 2019 tentang Penyelenggaraan Sistem dan Transaksi Elektronik. Ketidaktaatan korporasi tersebut menimbulkan implikasi yang sangat serius berupa terbukanya celah keamanan yang dapat dieksploitasi oleh pelaku kejahatan.

Pelaku kejahatan kerap kali memanfaatkan celah keamanan untuk melancarkan serangan siber. ${ }^{27} \mathrm{Hal}$ itu dapat dilihat berdasarkan data yang dilansir oleh kominfo yang mengungkapkan bahwa tingkat serangan siber di Indonesia masuk dalam peringkat ke dua di dunia. ${ }^{28}$ Dari data yang dilansir oleh Badan Siber dan Sandi Negara (BSSN) pada tahun 2020 tercatat 88,4 juta serangan siber yang ada di Indonesia, sebanyak 83\% di antaranya rentan terhadap korporasi. ${ }^{29}$ Serangan siber tersebut mayoritas berupa peretasan dan pencurian data pribadi yang berdampak pada bocornya data pribadi konsumen. Sebagaimana grafik berikut: ${ }^{30}$

Gambar 1. Peretasan dan Pencurian Data Pribadi di Indonesia Sepanjang Tahun 20172020.

${ }^{25}$ Wahyudi Djafar, “Hukum Perlindungan Data Pribadi Di Indonesia; Lanskap, Urgensi Dan Kebutuhan Pembaharuan," 2019, hlm 3, https://law.ugm.ac.id/wpcontent/uploads/sites/1043/2019/08/Hukum-Perlindungan-Data-Pribadi-di-Indonesia-Wahyudi-Djafar.pdf.

26 Anggara dkk, Menyeimbangkan Hak: Tantangan Perlindungan Privasi Dan Menjamin Akses Keterbukaan Informasi Dan Data Di Indonesia, hlm 11.

27 Ririn dkk Aswandi, "Perlindungan Data Dan Informasi Pribadi Melalui Indonesia Data Protection System (IDPS)," Legislatif 3, no. 2 (2020): hlm 168.

${ }^{28}$ Kementrian Komunikasi dan Informatika RI, "Laporan Tahunan Kementrian Kominfo Tahun 2019," 2020, https://www.kominfo.go.id/content/all/laporan_tahunan.

${ }^{29}$ Badan Siber dan Sandi Negara, "Laporan Tahunan 2019 PUSOPSKAMSINAS BSSN," 2020, https://bssn.go.id/laporan-tahunan-2019-pusopkamsinas-bssn/.

${ }^{30}$ Rommy Roossyana, "Pemerintah Mesti Melindungi Privasi Dan Data Pribadi Warganya," 2019, https://beritagar.id/artikel/berita/pemerintah-mesti-lindungi-privasi-dan-data-pribadi-warganya. 


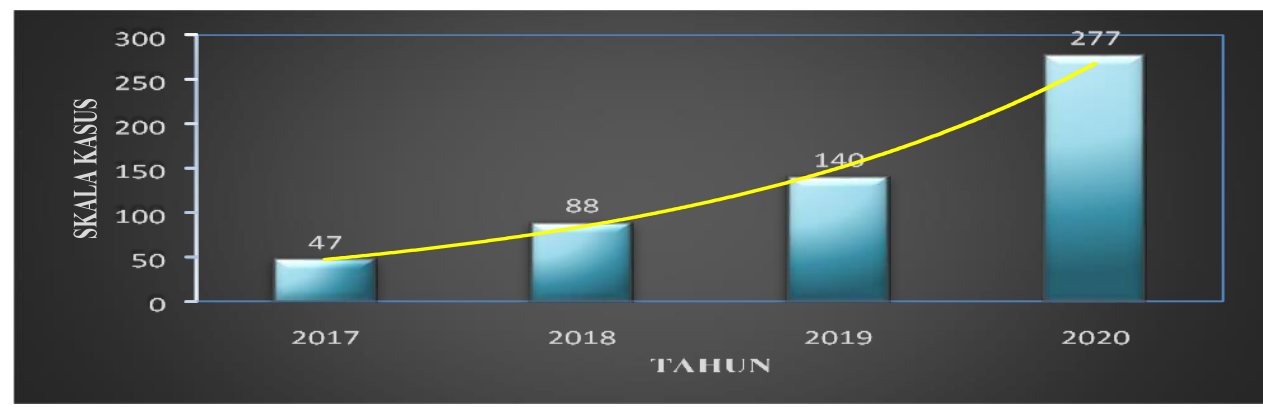

Berdasarkan data yang telah dilansir oleh Kepolisian Republik Indonesia (Polri), dapat ditemukan berbagai kasus peretasan dan pencurian data pribadi konsumen dalam kurun waktu tiga tahun terakhir. ${ }^{31}$ Pada tahun 2017, salah satu korporasi yang bergerak dibidang transportasi berbasiskan aplikasi yaitu PT Uber Indonesia Technology mengalami peretasan yang berujung pada pencurian data pengguna dan pengemudi Uber sebanyak 10.000 .000 akun. ${ }^{32}$ Pada tahun berikutnya, kasus serupa kembali menimpa 2 korporasi besar yaitu PT Facebook Indonesia dan PT Lion Mentari Airlines, di mana keduanya mengalami peretasan dan pencurian sebesar 8.800.000 akun pengguna. ${ }^{33}$ Pada tahun 2019, giliran PT. Sephora Indonesia dan PT. Bukalapak.com yang menjadi korban dari peretasan dan pencurian data akun pengguna. Kedua korporasi tersebut harus kehilangan 13.500.000 akun pengguna. Kasus peretasan dan pencurian data pengguna mencapai klimaks pada awal tahun 2020 yaitu melanda sedikitnya tiga korporasi dengan total data pengguna yang berhasil dicuri sebanyak 93.096.169 akun. Setelah berhasil memperoleh data-data pribadi para konsumen, pelaku kejahatan kerap kali memanfaatkannya baik itu untuk meraup keuntungan sebesarbesarnya atau untuk melancarkan kejahatan berikutnya yang dapat merugikan pemilik data sebagaimana skema berikut: ${ }^{34}$

Gambar 2. Skema Terkait Dampak dari Lemahnya Perlindungan Data Pribadi Konsumen dalam Korporasi.

${ }^{31}$ Pusat Informasi Kriminal Nasional, “Data Terkait Peretasan Dan Pencurian Data Pribadi Di Indonesia," 2020, https://pusiknas.polri.go.id/.

${ }^{32}$ Kumala Kurniawidi Susilo, “Kegagalan Internasionalisasi MNC Di Suatu Negara: Studi Kasus Kegagalan Internasionalisasi Uber Di Tiongkok," Repository Universitas Airlangga, 2018, http://repository.unair.ac.id/68087/3/Fis.HI.96.17 . Sus.k - JURNAL.pdf.

33 Cindy Mutia Annur, “Terulang Lagi, 267 Juta Data Pengguna Facebook Bocor," 2019, https://katadata.co.id/desysetyowati/digital/5e9a4c3de2b97/terulang-lagi-267-juta-data-penggunafacebook-bocor.

${ }^{34}$ Muhammad Na'im Al Jum'ah, “Analisa Kemanan Dan Hukum Untuk Perlindungan Data Privasi," Cyber Security Dan Forensik Digital 1, no. 2 (2018): hlm 40. 


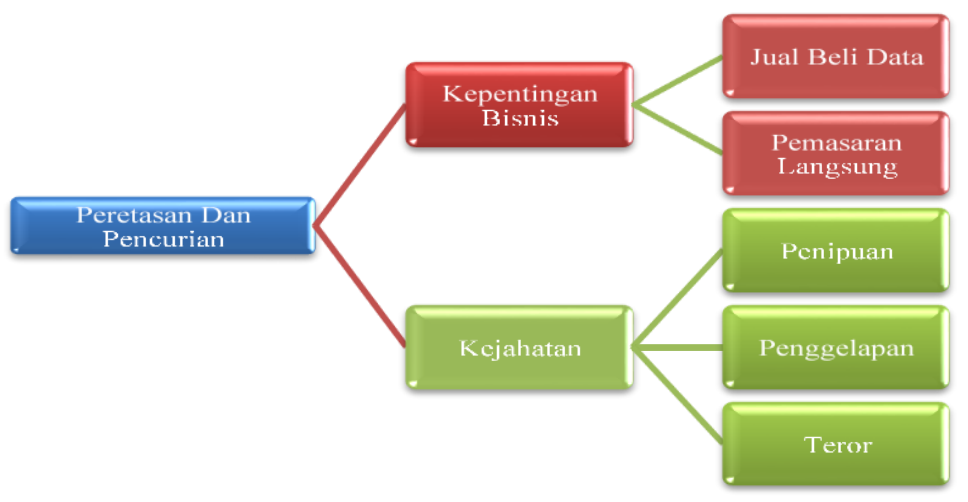

Berdasarkan skema di atas, terlihat bahwa data pribadi yang telah berhasil dicuri memiliki implikasi yang sangat buruk bagi konsumen sebagai pemilik data. Data-data pribadi mereka kerap kali diperjualbelikan kepada berbagai pihak demi kepentingan bisnis. Konsumen dijadikan objek dari pemasaran oleh korporasi untuk kepentingan profit sebagai bagian dari strategi pemasaran langsung (Direct marketing). ${ }^{35}$ Strategi tersebut menjadi pilihan utama dalam mempromosikan produk atau jasa mengingat tingkat efisiensi yang diraih cukup tinggi yaitu sekitar $30 \%$. ${ }^{36}$ Keuntungan tersebut di sisi lain sangat merugikan konsumen sebagai pemilik data pribadi, karena data yang bersifat privat dapat disalahgunakan secara materiil dan imateriil. ${ }^{37}$

Risiko akan penyalahgunaan data yang bersifat privat berpengaruh pula pada keamanan dan kedamaian masyarakat dalam cakupan yang lebih luas. Keadaan tersebut secara faktual benar-benar terjadi, karena data-data pribadi yang berada di tangan pihak ketiga yang tidak bertanggung jawab kerap kali digunakan untuk melancarkan aksi kejahatan berupa penipuan, penggelapan hingga teror atas nama pemilik dari data yang telah dicuri sebelumnya. Kasus penipuan dengan profil orang lain secara online sangat gencar terjadi, hal itu dibuktikan dari tingginya laporan yang diterima oleh tim patroli siber Direktorat Tindak Pidana Siber Bareskrim Polri pada tahun 2020 yang berjumlah 649 kasus. ${ }^{38}$ Praktik kejahatan lainnya yang tidak kalah masif yaitu praktik penggelapan, terutama yang berkenaan dengan kartu kredit. Para pelaku kejahatan umumnya menggunakan data pribadi nasabah untuk menduplikasikan kartu kredit dengan modus kehilangan.

Berdasarkan penelitian yang dilakukan oleh Communication and Information System Security Research Center, data pribadi nasabah pemegang kartu kredit biasa dicuri melalui situs-situs belanja online yang menimbulkan total kerugian mencapai 16.72

${ }^{35}$ Efendi, “Penyalahgunaan Kartu Tanda Penduduk (KTP) Untuk Registrasi Kartu Perdana (HP) Menurut Undang-Undang No.19 Tahun 2016 Tentang Informasi Transaksi Elektronik (ITE) Ditinjau Dari Fiqh Jinayah," hlm 3.

${ }^{36}$ Setiawan, "Revolusi Bisnis Platform Sebagai Penggerak Ekonomi Digital Di Indonesia," hlm 69.

${ }^{37}$ Asri Sitompul, Hukum Internet (Pengenalan Mengenai Masalah Hukum Di Cyberspace) (Bandung: PT Citra Aditya Bakti, 2001), hlm 38.

38 Patroli Siber, "Statistik Jumlah Laporan Polisi Yang Dibuat Masyarakat," 2020, https://patrolisiber.id/statistic. 
milyar. ${ }^{39}$ Sepanjang tahun 2020, terdapat 86 kasus terkait Financial Technology (Fintech) ilegal, di mana 39.5\% di antaranya berkaitan dengan cara penagihan yang tidak sesuai aturan, salah satunya dengan menggunakan pihak ketiga sebagai debt collector yang kerap melakukan teror kepada peminjam, sanak saudara hingga kerabat yang tidak berhubungan dengan aktivitas pinjam meminjam tersebut. ${ }^{40}$

Kegagalan konsep pengawasan yang selama ini menjadi tugas dan wewenang Kominfo serta aturan normatif yang masih bersifat sektoral dan parsial kiranya perlu direspons secara progresif untuk menghadirkan konsep yang menekankan independensi lembaga pengawas terhadap perlindungan data pribadi oleh korporasi. Tujuan dari adanya gagasan tersebut adalah untuk memastikan seluruh hak-hak konsumen tidak tercederai oleh aktivitas bisnis yang dilakukan korporasi. Perlindungan terhadap hak-hak konsumen, khususnya hak privasi merupakan satu kesatuan yang tidak terpisahkan dari grand design perlindungan hukum. Hal itu sesuai dengan tujuan hukum yang disampaikan oleh Prof. Satjipto Rahardjo bahwa hukum bertujuan bukan untuk berada pada status quo melainkan bergerak menciptakan kesejahteraan dan kebahagiaan manusia. ${ }^{41}$

\section{Relevansi Perlindungan Data Pribadi dengan Korporasi dalam Kerangka Konstitusi}

Negara hukum pada hakikatnya menempatkan hukum sebagai kekuasaan tertinggi dalam suatu negara. Seluruh alat perlengkapan negara harus tunduk dan patuh pada norma-norma yang telah digariskan dalam berbagai regulasi yang berlaku sebagai bentuk manifestasi dari hukum. Ciri utama dari konsep kedaulatan hukum ialah adanya konstitusi sebagai dasar tertinggi yang menjadi sumber utama bagi negara dalam menjalankan organisasi kekuasaannya. Konstitusi yang dimaksud pada tataran yang ideal semestinya memuat hal-hal fundamental yang berkaitan dengan hubungan negara dan warga negara. Hal itu dikarenakan konstitusi lebih dari sekedar hukum positif sebagaimana pendapat dari Frank I, Michelman yakni "a mirror reflecting the national soul, perhaps; an expression of national ideals, aspirations, and values expected, as such, to preside and permeate the process of judicial interpretation and judicial discretion throughout the lenght and breadth of the national legal order". ${ }^{42}$

Hubungan warga negara dengan negara harus dijamin dalam konstitusi demi tercapainya kemaslahatan rakyat. Hal itu sesuai dengan pandangan Anthony King dalam Omnus Opus nya yang berjudul The British Constitution bahwa "Legally and

${ }^{39}$ Communication \& Information System Security Research Center, “Waspada, Transaksi Di Sini Rawan Terjadi Pembobolan Kartu Kredit," 2019, https://www.cissrec.org/publications/detail/138/WaspadaTransaksi-di-Sini-Rawan-Terjadi-Pembobolan-Kartu-Kredit.htmlm.

40 Rayyan dan Erwin Hari Sentoso Sugangga, "Perlindungan Hukum Terhadap Pengguna Pinjaman Online (Pinjol) Ilegal," Pakuan Justice Journal Of Law 1, no. 1 (2020): hlm 48.

41 Satjipto Rahardjo, Hukum Progresif, Sebuah Sintesa Hukum Indonesia (Yogyakarta: Genta Publishing, 2009), hlm 25.

${ }^{42}$ Frank I Michelman, “The Constitution, Social Rights, and Liberal Political Justification,” I.CON 1, no. 1 (2003): hlm 13. 
constitutionally, using the law to regulate dangerous dogs and using it to protect human rights were in every way on all fours with one another". ${ }^{43}$ Anthony King berpandangan bahwa perlindungan terhadap human rights harus di bentuk sebuah regulasi di dalam sebuah konstitusi. Hal itu dikarenakan pembentuk Undang-Undang sering kali mengabaikan hak masyarakat dalam membentuk Undang-Undang sebagaimana yang diungkapkan A.V Dicey ${ }^{44}$

"A Bill for reforming the House of Commons, a Bill for abolishing the House of Lords, a Bill to give London a municipality, a Bill to make valid marriages celebrated by a pretended clergyman, found after their celebration not to be in orders, are each equally within the competence of Parliament, they may each be passed in substantially the same manner, they none of them when passed will be, legally speaking, a whit more sacred or immutable than the others, for they each will be neither more nor less than an Act of Parliament, which can be repealed as it has been passed by Parliament, and cannot be annulled by any other power."

Hak-hak konstitusional warga negara Indonesia telah tertuang dalam UUD NRI 1945 yang telah di amandemen sebanyak 4 kali yang terdiri dari hak kewarganegaraan, hak hidup, hak atas kebebasan meyakini kepercayaan, hak berserikat dan berkumpul, hak atas pekerjaan dan hidup layak, hak bebas dari ancaman, diskriminasi dan kekerasan, dan hak atas kemerdekaan menyampaikan pemikiran dan memilih.

Hak atas privasi sebagai salah satu hak konstitusional warganegara menjadi objek yang harus turut dilindungi negara melalui kristalisasi suatu hukum. Hal demikian disandarkan pada posisi bahwa privasi sebagai bagian dari diri setiap warga negara yang sangat krusial yang harus turut dilindungi negara sebagai bentuk tanggung jawab negara.

Negara dalam melindungi hak privasi memiliki dasar-dasar yang harus diperhatikan yaitu: ${ }^{45}$ (1) The right to privacy does not prohibit any publication of matter which is of public or general interest, (2) The right to privacy does not prohibit the communication of any matter, though in its nature private, (3) The law would probably not grant any redress for the invasion of privacy by oral publication in the absence of special damage, (4) The right to privacy ceases upon the publication of the facts by the individual, or with his consent, (5) The truth of the matter published does not afford a defence. Inilah dasar-dasar yang harus diperhatikan negara dalam menegakkan konsep hak privasi yang secara garis besar ada keikutsertaan rakyat dan negara dalam pembentukan kesepakatan perlindungan hak privasi.

Tanggung jawab negara terhadap perlindungan data pribadi yang terkristalisasi dalam UUD NRI 1945 secara simultan ditegaskan dengan keikutsertaan negara Indonesia meratifikasi Kovenan Internasional tentang Hak-Hak Sipil dan Politik pada

${ }^{43}$ Anthony King, The British Constitution (New York: Oxford University Press, 2007), hlm 21.

${ }^{44}$ Ivor and Anthony King Crewe, The Birth, Life and Death of the Social Democratic Party (Oxford: Oxford University Press, 1995), hlm 57.

45 Samuel D and Louis D. Brandeis Warren, "The Right to Privacy," Harvard Law Review 4, no. 5 (1980): hlm 214-218. 
28 Oktober 2005 yang dituangkan dalam Undang-Undang No. 12 Tahun 2005 tentang Pengesahan International Covenant on Civil and Political Rights.

Apabila menelisik ke dalam muatannya, di dalam Article of 17 International Covenant on Civil and Political Rights yang menegaskan bahwa "No one shall be subjected to arbitrary or unlawful interference with his privacy, family, home or correspondence, nor to unlawful attacks on his honour and reputation". Menurut Komite HAM PBB dalam pasal kovenan tersebut menjelaskan mengenai konsep 'gangguan yang sewenang-wenang (Arbitrary Interference)' tidak dapat diartikan sama dengan 'gangguan yang melawan hukum (Unlawful Interference)' yang sejalan dengan ketentuan dan tujuan Kovenan.

Arbitrary interference ialah bentuk gangguan yang dimungkinkan oleh undangundang, namun dalam penerapannya perlu pembatasan sejauh mana dapat mencampuri urusan pribadi seseorang. Sehubungan dengan hal itu, maka diperlukan sebuah organ negara yang melaksanakan dan mengawasi terkait campur tangan urusan pribadi seseorang sesuai dengan ketentuan dalam kovenan dan menjadi wadah untuk memberikan perlindungan terhadap hak yang diatur dalam ketentuan. ${ }^{46}$

Pada ranah implementasi, sejatinya negara tidak dapat berjalan sendiri melainkan Korporasi sebagai salah satu stakeholder harus turut berperan menegakkan instrumen hukum tersebut. Korporasi dapat dinilai baik jika telah dipercaya oleh para konsumen, maka korporasi sudah seharusnya menanamkan tata kelola yang baik dalam menjalankan sebuah usaha berdasarkan nilai-nilai Organization for Economic Cooperation and Development (OECD) yang diterapkan di seluruh dunia pada corporate governance di antaranya sebagai berikut: ${ }^{47}$

1. fairness: The corporate governance framework should protect shareholder rights and ensure the equitable treatment of all shareholders, including minority and foreign shareholders.

2. responsibility: The corporate governance framework should recognize the rights of stakeholders as established by law, and encourage active co-operation between corporations and stakeholders in creating wealth, jobs, and the sustainability of financially sound enterprises.

3. transparency: The corporate governance framework should ensure that timely and accurate disclosure is made on all material matters regarding the company, including its financial situation, governance structure, performance and ownership.

4. accountability: The corporate governance framework should ensure the strategic guidance of the company, the effective monitoring of management by the board, and the Board's accountability to the company and shareholders.

${ }^{46}$ Human Right Committee, “General Comment Article 17 (The Right to Respect, of Privacy, Family, Home and Correspondence, and Protection of Honour and Reputation)," Office of The High Commissioner for Human Rights 1 (1988): hlm 1-2.

${ }^{47}$ World Bank, “The Indonesia Corporate Governance Manual (English)” (Washington D.C., 2014), hlm 39, https://documents.worldbank.org/en/publication/documentsreports/documentdetail/551471487074479045/the-indonesia-corporate-governance-manual. 
Berkaca pada prinsip-prinsip yang dianut $O E C D$, setiap korporasi sudah seharusnya bertanggung jawab dan menaati sebagaimana peraturan perundangundangan yang mengatur korporasi dalam melangsungkan kegiatan-kegiatannya dengan memperhatikan hak stakeholder. ${ }^{48}$ Maka dari itu, ketika berbicara penggunaan data pribadi konsumen, korporasi haruslah mempertanggungjawabkan data pribadi dengan melakukan pemrosesan data pribadi sebagaimana tujuannya dan disetujui oleh pemilik data pribadi yang dikelolanya.

\section{Konsep Lembaga Pengawas terkait Perlindungan Data Pribadi yang Ideal}

Berdasarkan kerangka filosofis mengenai konsep hak privasi dan pengawasan perlindungan data pribadi, diperlukan suatu terobosan hukum berupa rekonsepsi terkait lembaga pengawas. Lembaga yang telah melakukan pengawasan terhadap korporasi terkait pengelolaan data pribadi para konsumen dijadikan satu sistem yang terintegrasi dengan membentuk suatu lembaga supervisi dan sub-ordinasi. Lembaga yang dimaksud berbentuk komisi atas nama Komisi Data Pribadi (KDP) yang dibentuk berdasarkan undang-undang khusus terkait perlindungan data pribadi. KDP berperan sebagai state auxiliary organ yang memiliki kedudukan setara dengan kementerian. Tujuan dari pembentukan KDP ialah untuk memastikan keamanan sistem elektronik terkait pengelolaan data pribadi pada korporasi sesuai dengan standar yang telah ditetapkan dalam peraturan perundang-undangan. Adapun berkenaan dengan struktur kelembagaan KDP dapat dilihat dalam skema di bawah ini:

Gambar 3 Struktur Kelembagaan KDP (Komisi Data Pribadi).

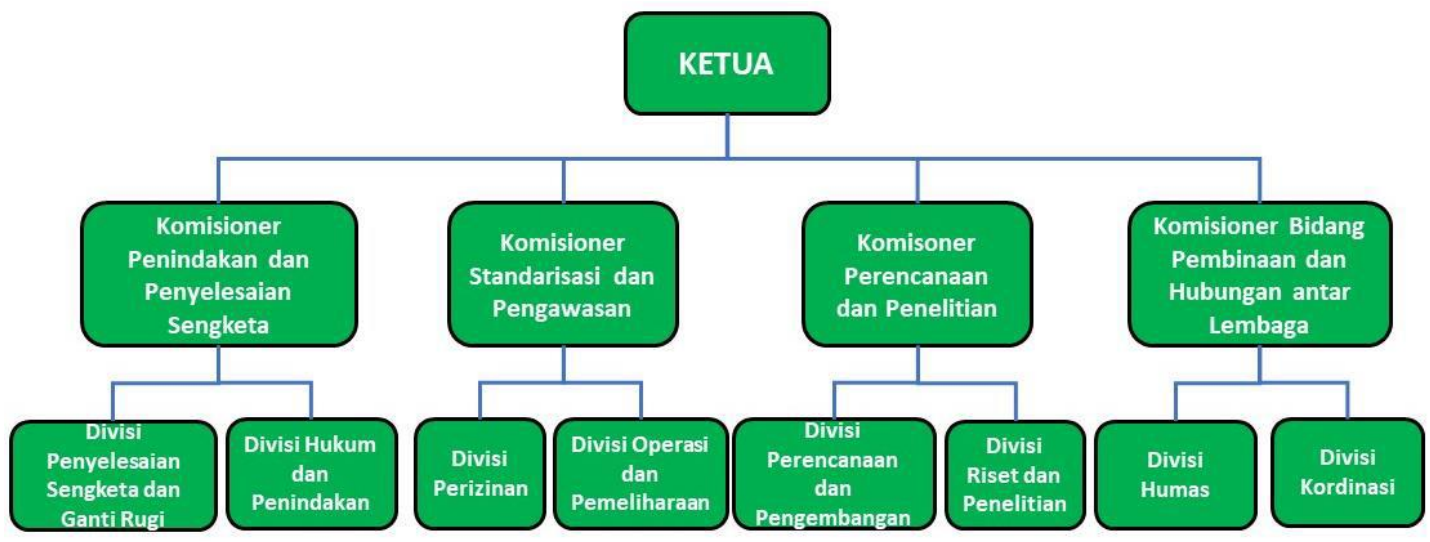

Komisi Data Pribadi (KDP) memiliki fungsi utama, di antaranya; Pertama, Menyelenggarakan sistem pengaturan dan pengawasan yang terintegrasi dengan seluruh kegiatan dalam sektor privat (korporasi). Kedua, Melaksanakan fungsi pengaturan dan pengawasan terhadap kegiatan pengumpulan, pengelolaan dan pemrosesan data pribadi disektor keuangan dan perbankan, perdagangan, perindustrian, serta telekomunikasi dan informatika. Ketiga, memberikan izin kelayakan kepada korporasi dan memberikan rekomendasi kepada pemerintah terkait strategi kebijakan perihal keamanan perlindungan data pribadi. Keempat, Melakukan

${ }^{48}$ World Bank, hlm 34. 
penindakan terhadap korporasi yang melakukan pelanggaran terkait pengelolaan data pribadi, serta menyelesaikan sengketa antar pihak.

Diranah preventif, KDP melalui divisi perizinan memiliki kewenangan untuk menerbitkan izin kelayakan atas keamanan sistem elektronik dalam pengumpulan, pengolahan dan pemrosesan data pribadi konsumen yang dilakukan oleh korporasi sebagai bagian integral dari upaya perlindungan data pribadi konsumen. Mekanisme perizinan dimulai dengan proses pendaftaran. Dilanjutkan dengan tahap presentasi dan simulasi yang dilakukan oleh korporasi terkait model pengumpulan, pengolahan dan pemrosesan data pribadi, kemudian diadakan pengujian oleh staf ahli dalam divisi perizinan. Setelah itu, KDP akan memeriksa kesiapan operasional terkait sistem elektronik keamanan data pribadi. Apabila seluruh persyaratan dan prosedur telah terpenuhi, maka KDP akan menerbitkan izin kelayakan kepada korporasi.

Izin kelayakan tentu saja diterbitkan berdasarkan ketentuan dalam peraturan perundang-undangan yang berlaku. Tidak hanya itu, KDP melalui Divisi Perizinan juga memperhatikan asas perlindungan data pribadi dan prinsip good corporate governance sebagai tolak ukur lainnya. Adapun asas perlindungan data pribadi yang dimaksud, meliputi penghormatan terhadap data pribadi sebagai privasi, kerahasiaan, persetujuan, relevansi dengan tujuan, itikad baik, tanggung jawab dan keutuhan, akurasi serta keabsahan data pribadi. Sementara itu, prinsip-prinsip good corporate governance itu sendiri meliputi keterbukaan (transparency), akuntabilitas (accountability), pertanggungjawaban (responsibility), dan kemandirian (independency).

Berdasarkan izin kelayakan yang telah diterbitkan oleh KDP, KDP berwenang untuk mengawasi korporasi perihal pengelolaan data pribadi konsumen. Melalui divisi operasi dan pemeliharaan, KDP mewajibkan korporasi untuk melaporkan annual report (Laporan Tahunan). Dalam rangka proses pemantauan, KDP akan menilai secara keseluruhan perihal layak atau tidaknya aktivitas pengumpulan, pengolahan dan pemrosesan data pribadi konsumen oleh korporasi. Sementara itu, untuk memenuhi prinsip transparansi, konsumen diperkenankan pula untuk mengakses database korporasi terkait data pribadi miliknya.

Gambar 4.4 Skema Mekanisme Investigasi oleh Komisi Data Pribadi

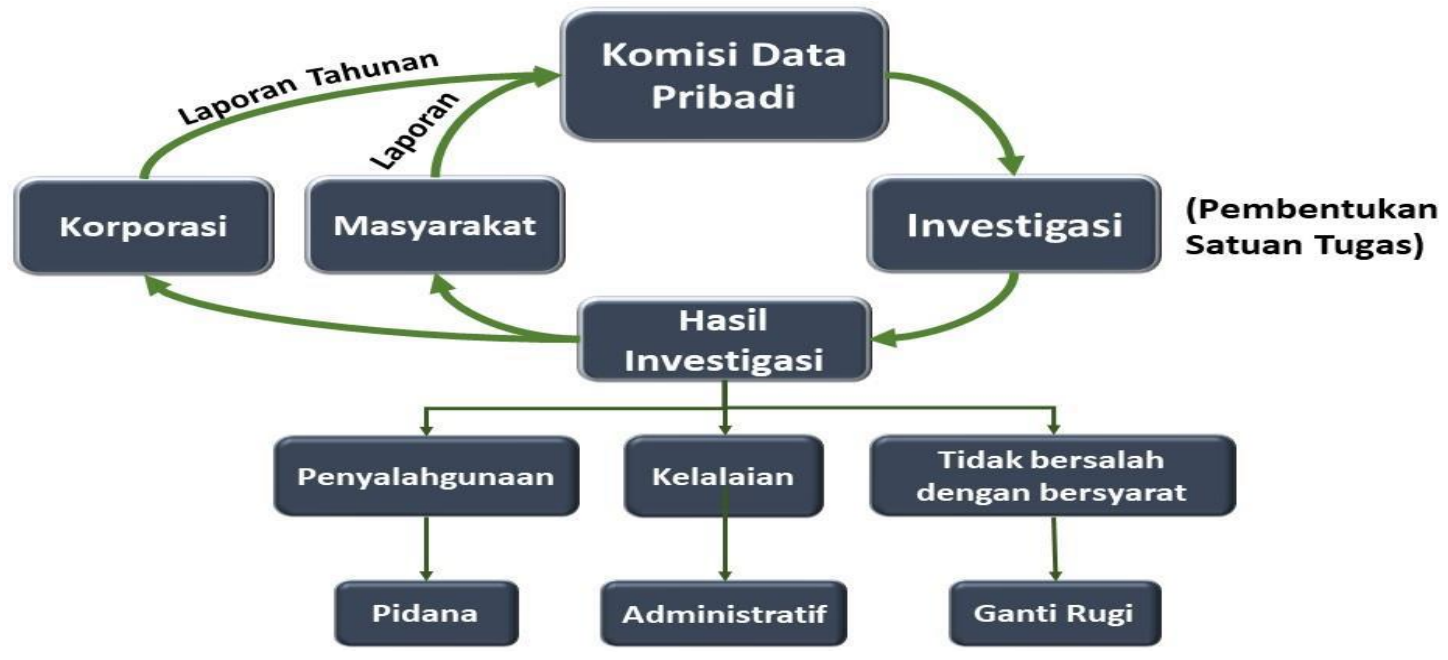


Apabila terjadi kebocoran data oleh korporasi, masyarakat dapat mengajukan laporan terkait adanya indikasi kebocoran data pribadi pada korporasi. Laporan yang berasal dari masyarakat akan diinvestigasi oleh KDP dengan membentuk satuan tugas yang beranggotakan dari pihak KDP dan korporasi. Satuan tugas yang dibentuk oleh KDP mempunyai wewenang untuk menginvestigasi secara langsung maupun tidak langsung terkait indikasi kebocoran data pribadi yang dialami korporasi. Kemudian, hasil investigasi tersebut akan dipublikasikan kepada masyarakat. Jika ditemukan adanya kebocoran data pribadi, KDP bersama instansi penegak hukum terkait akan menindaklanjuti secara hukum.

Perihal mekanisme pengaturan sanksi, jika terbukti adanya kebocoran data pribadi pada korporasi, maka akan mengarah kepada 3 kategori yakni Penyalahgunaan dengan sengaja, kelalaian terhadap standardisasi dan tidak bersalah dengan bersyarat.

- Jika korporasi melakukan penyalahgunaan dengan sengaja terhadap data pribadi, maka akan dikenakan sanksi administratif yang dapat berkembang menjadi sanksi pidana.

- Jika korporasi melakukan kelalaian terhadap standardisasi terkait perlindungan data pribadi, maka hanya akan dijatuhkan sanksi administratif.

- Jika korporasi dinyatakan tidak bersalah dengan bersyarat, maka tidak akan dikenakan sanksi administratif maupun pidana, namun tetap harus memenuhi persyaratan tertentu berupa pembayaran ganti rugi.

\section{KESIMPULAN}

Perlindungan data pribadi yang melibatkan korporasi di ranah privat secara faktual belum terlaksana dengan baik. Penyebab utamanya tidak lain dan tidak bukan karena terjadinya hyper regulation terkait perlindungan data pribadi Di Indonesia. Total regulasi yang mengatur terkait perlindungan data pribadi, khususnya di sektor bisnis berjumlah 30 undang-undang. Pengaturan yang tidak komprehensif itu semakin diperburuk pula dengan tidak optimalnya pengawasan yang dilakukan oleh Kominfo terhadap korporasi terkait pengumpulan, pengolahan dan pemrosesan data pribadi konsumen. Hal itu menimbulkan celah hukum yang kerap kali dieksploitasi oleh pelaku kejahatan untuk melancarkan serangan siber berupa peretasan dan pencurian yang menyasar data pribadi konsumen.

Masifnya kasus terkait peretasan dan pencurian data pribadi konsumen yang menimpa berbagai korporasi di tanah air mensinyalkan tanda bahaya yang harus ditangani dengan serius oleh negara. Reformasi hukum menjadi salah satu kunci utama yang harus dilakukan secara paripurna untuk mengatasi berbagai persoalan tersebut. Salah satu di antaranya yaitu dengan melakukan rekonsepsi terkait lembaga pengawas berupa pembentukan Komisi Data Pribadi. Komisi tersebut nantinya akan berjalan secara independen untuk memastikan seluruh data pribadi konsumen dapat terlindungi dengan baik sebagai bagian integral dari penegakan hak privasi berdasarkan konstitusi. 


\section{SARAN}

Berdasarkan data dan fakta yang ditemukan dalam penelitian kali ini, terdapat beberapa saran yang ditujukan kepada Presiden dan Dewan Perwakilan Rakyat (DPR) sebagai otoritas tertinggi di ranah legislasi. Pertama yaitu merancang suatu undangundang khusus untuk melindungi data pribadi konsumen. Berikutnya yaitu mencantumkan materi muatan terkait pembentukan lembaga baru bernama Komisi Data Pribadi dalam rancangan undang-undang tersebut untuk memastikan perlindungan terhadap data pribadi konsumen dapat terlaksana sesuai pranata hukum yang berlaku.

\section{REFERENSI}

Anggara dkk. Menyeimbangkan Hak: Tantangan Perlindungan Privasi Dan Menjamin Akses Keterbukaan Informasi Dan Data Di Indonesia. Jakarta: Institute for Criminal Justice Reform, 2015.

Anggraeni, Setyawati Fitri. "Polemik Pengaturan Kepemilikan Data Pribadi : Urgensi Untuk Harmonisasi Dan Reformasi Hukum Di Indonesia." Jurnal Hukum E Pembangunan 48, no. 4 (2018): 819.

Annur, Cindy Mutia. “Terulang Lagi, 267 Juta Data Pengguna Facebook Bocor," 2019. https://katadata.co.id/desysetyowati/digital/5e9a4c3de2b97/terulang-lagi-267-jutadata-pengguna-facebook-bocor.

Aswandi, Ririn dkk. "Perlindungan Data Dan Informasi Pribadi Melalui Indonesia Data Protection System (IDPS)." Legislatif 3, no. 2 (2020): 168.

Azharai. Negara Hukum Indonesia, Analisis Yuridis Normatif Tentang Unsur-Unsurnya. Jakarta: UI-Press, 1995.

Badan Siber dan Sandi Negara. "Laporan Tahunan 2019 PUSOPSKAMSINAS BSSN," 2020. https://bssn.go.id/laporan-tahunan-2019-pusopkamsinas-bssn/.

Communication \& Information System Security Research Center. "Waspada, Transaksi Di Sini Rawan Terjadi Pembobolan Kartu Kredit," 2019. https://www.cissrec.org/publications/detail/138/Waspada-Transaksi-di-SiniRawan-Terjadi-Pembobolan-Kartu-Kredit.htmlm.

Crewe, Ivor and Anthony King. The Birth, Life and Death of the Social Democratic Party. Oxford: Oxford University Press, 1995.

Dewi, Sinta. “Konsep Perlindungan Hukum Atas Privasi Dan Data Pribadi Dikaitkan Dengan Penggunaan Cloud Computing Di Indonesia." Yustisia 5, no. 1 (2016): 25.

- - - "Perlindungan Privasi Dan Data Pribadi Dalam Era Ekonomi Digital Di Indonesia." Veritas et Justitia 4, no. 1 (2018): 89.

Divisi Humas POLRI. “Menanti Ketegasan Komitmen Menjaga Keamanan Data Pribadi," 2020.

Djafar, Wahyudi. “Hukum Perlindungan Data Pribadi Di Indonesia; Lanskap, Urgensi 
Dan Kebutuhan Pembaharuan," 2019. https:/law.ugm.ac.id/wpcontent/uploads/sites/1043/2019/08/Hukum-Perlindungan-Data-Pribadi-diIndonesia-Wahyudi-Djafar.pdf.

Djafar, Wahyudi dan Asep Komarudin. Perlindungan Hak Atas Privasi Di Internet Beberapa Penjelasan Kunci. Jakarta: Elsam, 2014.

Doly, Denico. "Politik Hukum Pengaturan Perlindungan Data Pribadi." Pusat Penelitian Badan Keahlian DPR RI 10, no. 8 (2018): 3.

Efendi, Mareza. “Penyalahgunaan Kartu Tanda Penduduk (KTP) Untuk Registrasi Kartu Perdana (HP) Menurut Undang-Undang No.19 Tahun 2016 Tentang Informasi Transaksi Elektronik (ITE) Ditinjau Dari Fiqh Jinayah." Repository UIN Raden Fatah, 2020. http://repository.radenfatah.ac.id/6912/.

Hathaway, Oona A dkk. "The Law Of Cyber Attack." California Law Review 100, no. 4 (2012): 835.

Hidayat, Eko. "Perlindungan Hak Asasi Manusia Dalam Negara Hukum Indonesia." Jurnal Hukum Ekonomi Syariah 8, no. 2 (2016): 81.

Huda, Ni'Matul. Negara Hukum, Demokrasi Dan Judicial Review. Yogyakarta: UII-Press, 2005.

Human Right Committee. "General Comment Article 17 (The Right to Respect, of Privacy, Family, Home and Correspondence, and Protection of Honour and Reputation)." Office of The High Commissioner for Human Rights 1 (1988): 1-2.

Jum'ah, Muhammad Na'im Al. "Analisa Kemanan Dan Hukum Untuk Perlindungan Data Privasi." Cyber Security Dan Forensik Digital 1, no. 2 (2018): 40.

Kementrian Komunikasi dan Informatika RI. "Laporan Tahunan Kementrian Kominfo Tahun 2019," 2020. https://www.kominfo.go.id/content/all/laporan_tahunan.

King, Anthony. The British Constitution. New York: Oxford University Press, 2007.

Linn, Emily. "A Look Into the Data Privacy Crystal Ball: A Survey of Possible Outcomes for the EU-U.S Privacy." Vanderbilt Journal of Transnational Law 50 (2017): 1358.

Makarim, Edmon. Pengantar Hukum Telematika (Suatu Kompilasi Kajian). Jakarta: Rajagrafindo Persada, 2005.

Michelman, Frank I. "The Constitution, Social Rights, and Liberal Political Justification." I.CON 1, no. 1 (2003): 13.

Patroli Siber. “Statistik Jumlah Laporan Polisi Yang Dibuat Masyarakat,” 2020. https://patrolisiber.id/statistic.

Pusat Informasi Kriminal Nasional. “Data Terkait Peretasan Dan Pencurian Data Pribadi Di Indonesia," 2020. https://pusiknas.polri.go.id/.

Rahardjo, Satjipto. Hukum Progresif, Sebuah Sintesa Hukum Indonesia. Yogyakarta: Genta Publishing, 2009. 
Roossyana, Rommy. "Pemerintah Mesti Melindungi Privasi Dan Data Pribadi Warganya," 2019. https://beritagar.id/artikel/berita/pemerintah-mesti-lindungiprivasi-dan-data-pribadi-warganya.

Santoso, M. Agus. “Perkembangan Konstitusi Di Indonesia.” Yustisia 2, no. 3 (2013): 120.

Sautunnida, Lia. “Urgensi Undang-Undang Perlindungan Data Pribadi Di Indonesia Studi Perbandingan Hukum Inggris Dan Malaysia." Kanun 20, no. 2 (2018): 370.

Setiawan, Ahmad Budi. "Revolusi Bisnis Platform Sebagai Penggerak Ekonomi Digital Di Indonesia." Masyarakat Telematika Dan Informasi 9, no. 1 (2018): 69.

Setiyono. Kejahatan Korporasi. Malang: Bayumedia, 2003.

Sitompul, Asri. Hukum Internet (Pengenalan Mengenai Masalah Hukum Di Cyberspace). Bandung: PT Citra Aditya Bakti, 2001.

Sugangga, Rayyan dan Erwin Hari Sentoso. "Perlindungan Hukum Terhadap Pengguna Pinjaman Online (Pinjol) Ilegal." Pakuan Justice Journal Of Law 1, no. 1 (2020): 48 .

Susilo, Kumala Kurniawidi. "Kegagalan Internasionalisasi MNC Di Suatu Negara: Studi Kasus Kegagalan Internasionalisasi Uber Di Tiongkok." Repository Universitas Airlangga, 2018. http://repository.unair.ac.id/68087/3/Fis.HI.96.17 . Sus.k - JURNAL.pdf.

Utrecht. Pengantar Hukum Administrasi Negara Indonesia. Surabaya: Pustaka Tinta Mas, 1986.

Warren, Samuel D and Louis D. Brandeis. "The Right to Privacy." Harvard Law Review 4, no. 5 (1980): 214-18.

Westin, Alan. Privacy and Freedom. New York: Atheneum, 1967.

World Bank. "The Indonesia Corporate Governance Manual (English)." Washington D.C., 2014. https://documents.worldbank.org/en/publication/documentsreports/documentdetail/551471487074479045/the-indonesia-corporategovernance-manual. 